\title{
Trends for the formation of skin and fleece structure in the sheep stock breeding
}

\author{
O.K. Gogaev ${ }^{1,2 *}$, A.R. Demurova ${ }^{1}$, M.D. Basaeva ${ }^{1}$
}

${ }^{1}$ Gorsky State Agrarian University, 362040, RNO-Alania, Vladikavkaz, Kirov Street, 37; ${ }^{2}$ North Caucasus Research Institute of Mining and Foothill Agriculture - a branch of the Federal State Budgetary Institution of Science of the Federal Scientific Center "Vladikavkaz Scientific Center of the Russian Academy of Sciences", 363110, RNOAlania, Prigorodny district, Mikhailovskoye village, Williams Street, 1.

Corresponding author e-mail: texmen2@mail.ru

Journal of Livestock Science (ISSN online 2277-6214) 11:116-121

Received on 19/5/20; Accepted on 20/7/2020

doi. 10.33259/JLivestSci.2020.116-121

\begin{abstract}
One of the important issues of breeding is to develop animal breeding methods in order to improve their pedigree and productive qualities. To solve this issue, studies were conducted on farms of the Republic of North Ossetia-Alania. Age-related changes in the skin and fleece structure were studied using purebred and crossbred ewes, typical for their breed. The trend of age-related changes in the skin and fleece were studied using the adequate samples taken from the same experimental animals at different age periods. Preparations of skin specimens were produced and studied according to the method of N.A. Diomidova et al. (1960). The correlations between similar and dissimilar parameters of skin and fleece are determined. On their basis it is found that sheep within each breed have high positive correlations between similar and dissimilar parameters of skin and fleece. These correlations are found not only when comparing data in animals of the same age. Data on the correlation coefficients of the same sheep at birth, at an older age and in adulthood enable early selection of lambs according to the morphological parameters of the skin. The following parameters can be considered as main ones in the future wool productivity when selecting lambs at an early age within each breed and herd: - as fleece density parameters: follicles number per unit of skin area and in a group (complex), numerical ratio of the secondary follicles to primary ones; - the hair follicles depth as an index of the fleece length; - the ratio of the primary fibers fineness to secondary ones, as well as the primary hair follicles width to the width of secondary ones as fleece equal indices in fineness; - the ratio of the primary follicles depth to the depth of secondary ones as a fleece equal index in length.
\end{abstract}

Keywords: natural fleece length; hair follicles; correlation coefficient; wool clip; fleece thickness. 


\section{Introduction}

Sheep husbandry is backbone of economy of less privileged areas of the world which are also far away from urban areas and industrialization (Safdar, 2016; Das et al 2017). Sheep is reared mainly for wool and meat and hence fleece quantitative traits get importance in sheep breeding policy (de la Barra et al, 2014). At present, a rather rich research material on the skin and fleece structure of different sheep breeds rearing under various climatic and economic conditions has been accumulated (Gogaev et al., 2016a; Gogaev et al., 2012; Gogaev et al., 2016b; Trukhachev et al., 2018; Volkov et al., 2012).

A number of works pays special attention to establishing a mutual relationship between similar and dissimilar parameters of skin and fleece (Gogaev et al., 2019; Ismailov et al., 2003; Chernobai et al., 2003; Trukhachev et al., 2016; Dmitrik et al., 2017; Selionova et al., 2014; Dmitrik et al., 2017; Gogaev et al., 2016c). However, morphological parameters of the sheep skin and fleece in practical stock breeding are insufficiently used. Therefore, to develop recommendations on using correlation coefficients of some morphological parameters of the skin and fleece is of great theoretical and practical importance.

The main task of breeding in animal husbandry is to develop effective methods of selection and breeding that contribute to improve pedigree and increase productive qualities. One of the important issues of breeding is to develop animal breeding methods in order to improve their pedigree and productive qualities. Nowadays, early diagnosis of sheep productivity, based on objective research data, contributing to a significant acceleration of selection, is relevant. In this regard, the staff of Gorsky Agrarian University conducted quite rich experimental research and established correlations between histological parameters of the skin and wool productivity.

\section{Material and methods}

The present work was performed at the Department of Small animal science of Gorsky State Agrarian University. The experimental sheep stock was selected on the farms of the Republic of North Ossetia-Alania. Agerelated changes in the structure of skin and coat were studied in purebred sheep of the Grozny and Caucasian breeds and their crossbreeds in the amount of 100 heads in each group. In each experiment, feeding and housing conditions were taken into account. Fleece and skin samples were taken from the right ewes' side. The trend of age-related changes in the skin and fleece were studied using the adequate samples taken from the same experimental animals at different age periods. Preparations of skin specimens were produced and studied according to the method of N.A. Diomidova et al. (1960). The correlations between the similar and dissimilar parameters of the skin and fleece were calculated at the same age.

\section{Results}

When comparing the data on various traits in crossbred and purebred sheep with different fleece nature and productivity it was found positive correlations between some of similar and dissimilar traits both within the same age and between different age periods.

The level of sheep fleece productivity depends on many reasons. However, the fleece density and length are special among them. High positive correlations between the skin morphological parameters and the main indices that build the wool productivity have been established. Thus, the correlation coefficient of 12-month-old ewes between the depth of the primary hair follicles and the true fleece length was $0.92 \pm 0.040(\mathrm{P}<0.001)$ (Table 1). A high positive correlation coefficient $(0.67 \pm 0.077)$ was also observed between the number of hair follicles and the numerical ratio of $\mathrm{SF} / \mathrm{PF}$ per $1 \mathrm{~mm}^{2}$ of skin $(\mathrm{P}<0.001)$. Adequate calculations showed a positive correlation between the fleece length of 4-month-old and one-year-old ewes. The correlation coefficient for the true fleece length of the experimental animals in the given age periods was equal to: for the true fleece length $-+0.45 \pm 0.092(\mathrm{P}<0.001)$, and for natural one $-+0.83 \pm 0.058(\mathrm{P}<0.001)$. There was also a rather high positive correlation between the follicles density of 4-month-old and 12-month-old ewes.

All of these enables to select lambs aged 4 months according to the fleece length and density but in sheep breeding it is economically more expedient to select in the first days after birth, which is of great theoretical and practical importance. Defining tests for early diagnosis of sheep productivity will enable the breeder to refuse subjective techniques. Taking into account these considerations, the aim of this work is to determine the correlation between some skin and fleece parameters in different sheep breeds.

The data provided in table 1 show a high positive correlation between the studied parameters in lambs at birth and at 12 months. The correlation coefficient between the numerical SF/PF ratio in lambs at birth and at 12 months was $0.77 \pm 0.066(\mathrm{P}<0.001)$. The numerical $\mathrm{SF} / \mathrm{PF}$ ratio of newborn lambs positively correlates with the number of hair follicles per $1 \mathrm{~mm}^{2}$ of skin in the same 12 -month-old ewes $(0.72 \pm 0.072, \mathrm{P}<0.001)$. Consequently, the value of SF/PF ratio in newborn lambs may be a good parameter of the follicles density in the same 12-month-old animals. It is more likely that the number of hair follicles and the numerical SF/PF ratio in the group does not decrease with age (Table 2).

Using a relatively large sheep stock, it was found that the fleece density is not only a breed but also individual character, which in most cases remains during the life of the animal. Ewes, with a large number of hair follicles in the group and per unit of skin area at birth, remain more thick-fleeced in subsequent age periods as well. 
According to the data of individual wool clip and the number of hair follicles per $1 \mathrm{~mm}^{2}$ of skin area, it was found that in most cases lambs with a high number of hair follicles at birth produce more wool clip.

Table 1 shows that the correlation coefficients between the follicles number in the group and per $1 \mathrm{~mm}^{2}$ of skin area, on the one hand, and wool clip at 12 months, on the other hand, were equal to $0.74 \pm 0.069(\mathrm{P}<0.001)$; $0.73 \pm 0.070(\mathrm{P}<0.001)$ respectively.

For clarity, all experimental ewes were divided into two groups to show the dependence of wool clip on the number of hair follicles. One group included animals which had less follicles per $1 \mathrm{~mm}^{2}$ of skin area at birth than on average in the whole group (average number of follicles is $243 / \mathrm{mm}^{2}$ ), another group included animals, which had more follicles. The first group is imprecisely called thin-fleeced, the second - thick-fleeced. Data on the wool clip in the given groups of animals and the average parameters for both groups are shown in table 3 .

As shown in table 3,14-month-old ewes of the thick-fleeced group produced $1.38 \mathrm{~kg}$ or $41 \%$ more fleece than thin-fleeced one. This difference was mathematically significant. The experimental groups of ewes were properly selected according to live weight, fleece length and body area. Thus, the average live weight of thin-fleeced ewes was $35.6 \mathrm{~kg}$, the fleece length was $7.8 \mathrm{~cm}$, for thick-fleeced $-36.7 \mathrm{~kg}$ and $7.68 \mathrm{~cm}$ respectively.

The body area was about the same and equal to: in the first group $-79.3 \mathrm{dm}^{2}$, in the second $-83.4 \mathrm{dm}^{2}$. Hence, these data also indicate that the difference in the wool clip is the result of different fleece densities.

Taking into account the wool yield, which is equal, on average, to $47.0 \%$ in the first group and $52.7 \%$ in the second group, the real difference in the wool clip in the compared groups of ewes increases significantly. The research found that the fleece equal in fineness and length largely depend on values showing the ratio of the primary hair follicles depth to the depth of secondary ones, as well as the ratio of the primary hair follicles width to the width of secondary ones.

The experimental ewes showed a positive correlation between the ratio of the primary fibers fineness to secondary ones at birth and the ratio of the primary follicles depth to the depth of secondary ones at 12 months. The correlation coefficient between these traits was $0.39 \pm 0.095$ with a quite high test of significance $(\mathrm{P}<0.001)$. Based on the data obtained, it could be argued that the hair follicles depth is closely related to the fleece length.

The above data included the age-related changes in the skin and fleece of fine-coarse-fleece crossbred sheep with different fleece nature. The calculations showed that the correlation coefficient between the primary hair follicles depth and the primary fibers length of 12-month-old experimental ewes was very high and ranged from $0.92 \pm 0.14$ to $0.99 \pm 0.04(\mathrm{P}<0.001)$. The same trend is observed between the secondary follicles depth and the secondary fibers length. The correlation coefficient between the given traits at 12 months was equal to: in coarsewooled $-0.92 \pm 0.14(\mathrm{P}<0.001)$, in semi-coarse-wooled $-0.79 \pm 0.20(\mathrm{P}<0.001)$, in semi-fine-fleece $-0.86 \pm 0.16$ $(\mathrm{P}<0.001)$ and fine-fleece $-0.98 \pm 0.02(\mathrm{P}<0.001)$.

The follicles depth also affects the fleece fineness. With increasing the follicles depth, the diameter of the fibers cross section increases. It is known that the number of hair follicles greatly affects the wool yield. The correlation coefficient according to these parameters in 12-month-old ewes with different fleece nature was: for coarse-wooled $-0.98 \pm 0.06(\mathrm{P}<0.001)$, for semi-coarse-wooled $-0.96 \pm 0.09(\mathrm{P}<0.001)$, for semi-fine-fleece $0.94 \pm 0.10(\mathrm{P}<0.001)$ and fine-fleece $-0.99 \pm 0.06(\mathrm{P}<0.001)$.

There is a high positive correlation between some parameters at birth and at 12 months. For example, accordingly to the primary follicles depth, it was equal to: in coarse-wooled $-0.93 \pm 0.13(\mathrm{P}<0.001)$, semi-coarsewooled $-0.98 \pm 0.06(\mathrm{P}<0.001)$, semi-fine-fleece $-0.98 \pm 0.06(\mathrm{P}<0.001)$, fine-fleece $-0.98 \pm 0.08(\mathrm{P}<0.001)$.

A high positive correlation was obtained between the hair follicles depth and the fiber length at 12 months. On the other hand, there is a positive correlation between the fibers depth at birth and at 12 months. Therefore, there should be a positive correlation between the hair follicles depth at birth and the fibers length at 12 months.

Appropriate data processing found that these parameters in ewes with different fleece nature were equal in the groups, respectively: for primary follicles $-0.98 \pm 0.05(\mathrm{P}<0.001) ; 0.95 \pm 0.10(\mathrm{P}<0.001) ; 0.98 \pm 0.06(\mathrm{P}<0.001)$; $0.98 \pm 0.08(\mathrm{P}<0.001)$; for secondary follicles $-0.92 \pm 0.14(\mathrm{P}<0.001), 0.95 \pm 0.10(\mathrm{P}<0.001) ; 0.89 \pm 0.14(\mathrm{P}<0.001)$, $0.97 \pm 0.08(\mathrm{P}<0.001)$.

Thick-fleeced newborn lambs had a greater number of hair follicles per unit of skin area in subsequent age periods as well. The correlation coefficient between the number of follicles at birth and at 12 months averaged for the corresponding groups: $0.99 \pm 0.06 ; 0.96 \pm 0.09 ; 0.95 \pm 0.10$ and $0.91 \pm 0.15$, wherein the test of significance was high $(\mathrm{P}<0.001)$.

As stated above, the numerical ratio of the secondary follicles to primary ones does not change with age, and may be used as a parameter of fleece density. This is also proved by the correlation data of this parameter at birth and at 12 months, which were positive, equal for the corresponding groups: $0.79 \pm 0.22(\mathrm{P}<0.001), 0.99 \pm 0.06$ $(\mathrm{P}<0.001), 0.78 \pm 0.20(\mathrm{P}<0.001), 0.71 \pm 0.25(\mathrm{P}<0.001)$.

A high positive correlation with the test of significance also exists between the numerical ratio of the secondary follicles to primary ones at birth and the number of hair follicles per $1 \mathrm{~mm}^{2}$ of skin area at 12 months. In the experimental groups of ewes, the correlation coefficients between the given parameters were quite high, and equal to: for coarse-wooled ewes $-0.88 \pm 0.17$ ( $\mathrm{P}<0.001)$, semi-coarse-wooled $-0.92 \pm 0.12(\mathrm{P}<0.001)$, semi-finefleece $-0.89 \pm 0.15(\mathrm{P}<0.001)$, fine-fleece $0.27 \pm 0.13$. This reconfirms the possibility of using $\mathrm{SF} / \mathrm{PF}$ as a parameter of fleece density. 
Table 1 - Correlation coefficients between histological parameters of the skin and fleece in the crossbred fine-fleece ewes at birth and at 12 months $(n=95)$

\begin{tabular}{|c|c|c|}
\hline \multicolumn{2}{|c|}{ Parameters } & \multirow{2}{*}{$\mathrm{r} \pm \mathrm{m}_{\mathrm{r}}$} \\
\hline At birth & 12 months & \\
\hline SF/PF number & SF/PF number & $0.77 \pm 0.066$ \\
\hline SF/PF number & the follicles number per $1 \mathrm{~mm}^{2}$ & $0.72 \pm 0.072$ \\
\hline PF depth & natural fleece length & $0.82 \pm 0.059$ \\
\hline PF depth & true fleece length & $0.75 \pm 0.69$ \\
\hline The follicles number in the group & wool clip & $0.74 \pm 0.069$ \\
\hline The follicles number per $1 \mathrm{~mm}^{2}$ & wool clip & $0.73 \pm 0.070$ \\
\hline PF/SF depths & PF/SF fineness & $0.39 \pm 0.095$ \\
\hline
\end{tabular}

PF - primary follicles; SF - secondary follicles

Table 2 - The total hair follicles in the group and SF/PF per $1 \mathrm{~mm}^{2}$ of the experimental ewes' skin in different age periods

\begin{tabular}{|l|l|l|l|l|l|l|l|}
\hline \multirow{2}{*}{ Age } & \multirow{2}{*}{$\mathrm{n}$} & \multicolumn{2}{c|}{ Follicles in the group } & \multicolumn{2}{c|}{ SF/PF per $1 \mathrm{~mm}^{2}$} \\
\cline { 3 - 8 } & & $\mathrm{M} \pm \mathrm{m}$ & $\sigma$ & $\mathrm{C}_{\mathrm{v}}$ & $\mathrm{M} \pm \mathrm{m}$ & $\sigma$ & $\mathrm{C}_{\mathrm{v}}$ \\
\hline At birth & 100 & $14.58 \pm 1.82$ & 0.18 & 1.24 & $11.92 \pm 0.12$ & 1.92 & 10.00 \\
\hline 4 months & 87 & $14.69 \pm 0.04$ & 0.38 & 2.58 & $11.85 \pm 0.12$ & 1.23 & 10.34 \\
\hline 12 months & 95 & $14.71 \pm 0.04$ & 0.39 & 2.60 & $12.54 \pm 0.26$ & 2.52 & 20.10 \\
\hline 24 months & 82 & $14.82 \pm 0.11$ & 0.96 & 6.50 & $12.48 \pm 0.19$ & 1.72 & 13.70 \\
\hline
\end{tabular}

Table 3 - Wool clip in experimental groups of 14-month-old ewes

\begin{tabular}{|l|c|c|c|c|c|}
\hline \multicolumn{1}{|c|}{ Group } & $\mathrm{n}$ & $\mathrm{M} \pm \mathrm{m}$ & $\mathrm{Lim}$ & 6 & $\mathrm{C}_{\mathrm{v}}$ \\
\hline Thin-fleeced & 55 & $3.37 \pm 0.025$ & $2.8-4.0$ & 0.19 & 5.46 \\
\hline Thick-fleeced & 40 & $4.75 \pm 0.009$ & $4.0-5.5$ & 0.06 & 1.20 \\
\hline Average & 95 & $3.93 \pm 0.045$ & $2.8-5.5$ & 0.44 & 11.30 \\
\hline
\end{tabular}

Table 4 - Correlation coefficients between histological parameters of the skin and fleece in ewes of Kavkazskaya breed at birth and 9 months $(n=50)$

\begin{tabular}{|c|c|c|}
\hline \multicolumn{2}{|c|}{ Parameters } & \multirow[t]{2}{*}{$\mathrm{r} \pm \mathrm{m}_{\mathrm{r}}$} \\
\hline At birth & 9 months & \\
\hline The follicles number in the group & the follicles number in the group & $0.97 \pm 0.037$ \\
\hline The follicles number per $1 \mathrm{~mm}^{2}$ & the follicles number per $1 \mathrm{~mm}^{2}$ & 0.620 .113 \\
\hline $\mathrm{SF} / \mathrm{PF}$ in the group & $\mathrm{SF} / \mathrm{PF}$ in the group & $0.68 \pm 0.106$ \\
\hline $\mathrm{SF} / \mathrm{PF}$ per $1 \mathrm{~mm}^{2}$ & $\mathrm{SF} / \mathrm{PF}$ per $1 \mathrm{~mm}^{2}$ & $0.23 \pm 0.141$ \\
\hline PF depth & PF depth & $0.92 \pm 0.056$ \\
\hline SF depth & SF depth & $0.81 \pm 0.085$ \\
\hline PF/SF depth & PF/SF depth & $0.88 \pm 0.068$ \\
\hline PF depth & natural fleece length & $0.67 \pm 0.105$ \\
\hline
\end{tabular}

Table 5 - Correlation coefficients between histological parameters of the skin and fleece in sheep of Groznenskaya breed at birth and 24 months

\begin{tabular}{|c|c|c|}
\hline \multicolumn{2}{|c|}{ Parameters } & \multirow[t]{2}{*}{$\mathrm{r} \pm \mathrm{m}_{\mathrm{r}}$} \\
\hline At birth & 24 months & \\
\hline The follicles number in the group & the follicles number in the group & $0.93 \pm 0.069$ \\
\hline The follicles number per $1 \mathrm{~mm}^{2}$ & the follicles number per $1 \mathrm{~mm}^{2}$ & $0.85 \pm 0.099$ \\
\hline $\mathrm{SF} / \mathrm{PF}$ in the group & SF/PF in the group & $0.38 \pm 0.175$ \\
\hline $\mathrm{SF} / \mathrm{PF}$ per $1 \mathrm{~mm}^{2}$ & $\mathrm{SF} / \mathrm{PF}$ per $1 \mathrm{~mm}^{2}$ & $0.59 \pm 0.153$ \\
\hline PF depth & PF depth & $0.91 \pm 0.079$ \\
\hline SF depth & SF depth & $0.98 \pm 0.036$ \\
\hline PF width & PF width & $0.82 \pm 0.107$ \\
\hline SF width & SF width & $0.93 \pm 0.069$ \\
\hline PF depth & true fleece length & $0.95 \pm 0.060$ \\
\hline SF depth & true fleece length & $0.92 \pm 0.075$ \\
\hline SF/PF in the group & wool clip & $0.57 \pm 0.156$ \\
\hline $\mathrm{SF} / \mathrm{PF}$ per $1 \mathrm{~mm}^{2}$ & wool yield & $0.40 \pm 0.173$ \\
\hline
\end{tabular}


Table 6 - Correlation coefficients between histological parameters of the skin and fleece in sheep of Osetinskaya breed at birth and 24 months

\begin{tabular}{|c|c|c|}
\hline \multicolumn{2}{|c|}{ Parameters } & $\mathrm{r} \pm \mathrm{m}_{\mathrm{r}}$ \\
\hline At birth & 24 months & \\
\hline The follicles number in the group & the follicles number in the group & $0.87 \pm 0.093$ \\
\hline The follicles number per $1 \mathrm{~mm}^{2}$ & the follicles number per $1 \mathrm{~mm}^{2}$ & $0.83 \pm 0.105$ \\
\hline SF/PF in the group & SF/PF in the group & $0.70 \pm 0.087$ \\
\hline $\mathrm{SF} / \mathrm{PF}$ per $1 \mathrm{~mm}^{2}$ & $\mathrm{SF} / \mathrm{PF}$ per $1 \mathrm{~mm}^{2}$ & $0.54 \pm 0.160$ \\
\hline PF depth & PF depth & $0.64 \pm 0.145$ \\
\hline SF depth & SF depth & $0.79 \pm 0.116$ \\
\hline PF width & PF width & $0.98 \pm 0.041$ \\
\hline SF width & SF width & $0.92 \pm 0.073$ \\
\hline PF depth & true fleece length & $0.74 \pm 0.127$ \\
\hline $\mathrm{SF} / \mathrm{PF}$ per $1 \mathrm{~mm}^{2}$ & wool yield & $0.38 \pm 0.175$ \\
\hline The follicles number in the group & wool yield & $0.91 \pm 0.077$ \\
\hline
\end{tabular}

Our research confirms a direct correlation between the number of hair follicles and sheep's wool clip. The number of hair follicles per $1 \mathrm{~mm}^{2}$ of newborn lambs' skin may tell the future wool productivity of sheep. The correlation coefficients between the number of hair follicles per $1 \mathrm{~mm}^{2}$ of skin at birth and wool yield at 12 months were equal to: in coarse-wooled sheep $-0.98 \pm 0.06(\mathrm{P}<0.001)$, in semi-coarse-wooled $-0.89 \pm 0.15(\mathrm{P}<0.001)$, in semi-fine-fleece $-0.97 \pm 0.07(\mathrm{P}<0.001)$, in the fine-fleece $-0.98 \pm 0.07(\mathrm{P}<0.001)$.

The data provided above show the correlations between different skin and fleece parameters of fine-coarsefleece crossbred sheep with different fleece nature. Similar research was done using purebred sheep of Groznenskaya, Kavkazskaya and Osetinskaya breeds. The material, provided below, and its analysis confirm our data, obtained using crossbred animals, on high positive correlations between lambs' traits at birth and at an older age.

The data in table 4 show that sheep of Kavkazskaya breed have high positive correlations between the similar parameters in lambs at birth and at 9 months. The correlation coefficient between the follicles number in the group was $0.97 \pm 0.037$, per $1 \mathrm{~mm}^{2}-0.62 \pm 0.113$. Moreover, in both cases there were high tests of significance $(\mathrm{P}<0.001)$. A rather high correlation coefficient, equal to $0.68 \pm 0.106(\mathrm{P}<0.001)$, is provided in the numerical ratio of the secondary follicles to primary ones in the group. The same parameter calculated for the follicles number per 1 $\mathrm{mm}^{2}$ was significantly lower $(0.23 \pm 0.141)$.

The data in table 4 show that the follicles depth in newborn lambs positively correlates with those at 9 months but the correlation coefficient for the primary follicles is higher $(0.92 \pm 0.056)$ than for secondary ones $(0.81 \pm 0.085)$. In turn, the depth of the primary hair follicles in newborn lambs positively correlates with the natural fleece length of 9 -month-old ewes $(0.67 \pm 0.105)$. Thereby, it was found that the same lambs at birth and 9 months have high positive correlations between different parameters.

The data in table 5 that show values of the correlation coefficients in the same animals of Groznenskaya breed at birth and 24 months are of rather great interest. As expected, high, positive and significant correlations are observed between the traits of newborn and adult sheep of Groznenskaya breed. A similar pattern was obtained in appropriate processing the data research of sheep skin and fleece of Osetinskaya coarse-wooled breed (Table 6).

The data provided in table 6 show high positive correlation coefficients between the sheep traits at birth and 24 months. For example, the correlation coefficients for the follicles number in the group, per $1 \mathrm{~mm}^{2}$ of skin area and the numerical ratio of the secondary follicles to primary ones in the group and per $1 \mathrm{~mm}^{2}$ of skin, were equal to, respectively: $0.87 \pm 0.093 ; 0.83 \pm 0.105 ; 0.70 \pm 0.87 ; 0.54 \pm 0.160$. Moreover, the tests of significance were high $(\mathrm{P}<0.001)$.

Lambs having higher follicles number per unit skin area at birth remain more thick-fleeced in adulthood as well, which reconfirms the possibility of selecting sheep at an early age according to the fleece density. The same applied to the hair follicles depth.

The correlation coefficients between the parameters of the newborn lambs and tegs were also high. The data on the correlation coefficients for the follicles width are of interest. The fact is that the parameters of the hair follicles width positively correlate with the fibers fineness and the ratio of the primary hair follicles width to the width of secondary ones is negative with the wool equal. The correlation coefficients of follicles width in animals at birth and 24 months were very high, equal to $0.98 \pm 0.041$ for the primary hair follicles; for secondary ones $0.92 \pm 0.073$. As in previous cases, there is a high positive correlation between the hair follicles depth at birth and the fleece length at 24 months, as well as between the follicles number or SF/PF ratio and wool clip. Thus, the correlations in the studied sheep are obviously common to all sheep breeds.

The foregoing data resulted in the following conclusions:

1. High positive correlations are observed between the similar and dissimilar parameters of skin and fleece within each sheep breed.

2. The obtained data on the correlation coefficients of the same sheep at birth, at an older age and in adulthood 
enable early selection of lambs according to the morphological parameters of the skin;

3. The following parameters can be considered as main ones in the future wool productivity when selecting lambs at an early age within each breed and herd:

a) fleece density parameters: follicles number per unit of skin area and in a group (complex), numerical ratio of the secondary follicles to primary ones;

b) the hair follicles depth as an index of the fleece length;

c) the ratio of the primary fibers fineness to secondary ones, as well as the primary hair follicles width to the width of secondary ones as fleece equal indices in fineness;

d) the ratio of the primary follicles depth to the depth of secondary ones as a fleece equal index in length.

\section{References}

1) Chernobai, E.N. 2003. The skin histostructure and hair follicles density in Kavkazskaya ewes of intra-and interline selection E.N. Chernobai. Relevant issues of animal science and practice, as the basis for improving the productive qualities and health of farm animals: materials of the $2^{\text {nd }}$ International scientific-practical conference, Stavropol: StGAU “AGRUS”. - pp. 207-210.

2) Das H., Ali M.A., Devi L.I., Kirthika P., Gali J.M.R. and Behera P. 2017. Studies on some important enzymes of non-descript sheep of Assam. Journal of Livestock Science (ISSN online 2277-6214) 8: 59-62

3) de la Barra R., Martínez M.E. and Calderón C. 2014. Phenotypic features and fleece quantitative traits in Chilota sheep breed. Journal of Livestock Science (ISSN online 2277-6214) 5:28-34.

4) Diomidova N.A., Panfilova E.P., Suslina E.S. 1960. Methods of studying hair follicles in sheep. IMZH, M. - p. 43.

5) Dmitrik I.I. 2017. Use of histological parameters in assessing the quality of sheep production. Agricultural Bulletin of Stavropol Region. 1 (25): 87-91.

6) Gogaev O.K., Kessaev Kh.E., Demurova A.R. 2012. Trends for the formation of skin and fleece of crossbred sheep in the conditions of the Central Ciscaucasia. Proceedings of Gorsky State Agrarian University. Vladikavkaz. 49(3): 100-113.

7) Gogaev O.K., Kessaev Kh.E., Demurova A.R., Bestaeva R.D., Dzeranova A.V. 2016a. Formation of wool follicles in the skin of young sheep of different origin. Scientific life. 12: 58-67.

8) Gogaev O.K., Kessaev Kh.E., Demurova A.R., Gattsiev U.S. 2016b. Trends for formation of skin and hair follicles of young Romanov sheep in foothill conditions of the North Caucasus. Proceedings of Gorsky State Agrarian University. - Vladikavkaz. 53(1): 50-57.

9) Gogaev, O.K., Kessaev, Kh.E., Kaloev, B.S., Kebekov, M.E., Tarchokov, T.T. 2016c. Formation of skin and hair coat of the Romanov sheep in the conditions of the piedmont of the North Caucasus. Asian Journal of Microbiology, Biotechnology and Environmental Sciences. 18(4): 1027-1036.

10) Gogaev O.K., Yuldashbaev Yu.A., Kebekov M.E., Kairov V.R., Kaloev B.S., Demurova A.R. 2019. The features of sheep adaptation to their keeping in mountainous conditions. Indo American Journal of Pharmaceutical Sciences. 6(9): 15653-15661.

11) Ismailov I.S., Gogaev O.K. 2003. Productivity and histological structure of the skin in sheep with heterogeneous fleece. Sheep, goats, woolen business. 1: 35-36.

12) Safdar A.H.A. 2016, S.P.M.G. Maghami and A.E. Nejad 2016. Effects of different lipids and energy supplements on reproductive biological characteristics of 'Afshari' ewes in Iran. Journal of Livestock Science 7: 172-179.

13) Selionova, M.I., Dmitrik I.I., Zavgorodnyaya G.V. 2014. Microstructural assessment of meat quality of different directions in productivity. Animal science. 11:26-27.

14) Trukhachev V.I., Chernobai E.N. 2018. Selection and genetic methods for increasing the productivity of finefleece sheep breeds in the North Caucasus. Stavropol. p. 220

15) Trukhachev V.I., Moroz V.A., Chernobai E.N., Ismailov I.S. 2016. Meat and interior features of rams of different genotypes. Research Journal of Pharmaceutical, Biological and Chemical Sciences. 2016. 7(1): 1626-1630.

16) Volkov I.V., Khamiruev T.N., Tudunov Z.B. 2012. Inheritance of the main economically useful traits of a new sheep type of Zabaikalskaya fine-fleece breed. Agrarian science - agricultural production in Siberia, Mongolia, Kazakhstan and Bulgaria: materials of the $\mathrm{XV}^{\text {th }}$ International scientific and practical conference Petropavlovsk. 2: 61-64. 